\title{
COXEN Score 22
}

National Cancer Institute

\section{Source}

National Cancer Institute. COXEN Score 22. NCI Thesaurus. Code C128219.

A score of 22 on the COXEN Sensitivity Scale. 